\section{Palynological model of the Late Neogene sediments of Eastern Slavonia (Croatia)}

The Mining-Geology-Petroleum Engineering Bulletin UDC: 551.311 .2

DOI: 10.17794/rgn.2015.2.3

Original scientific paper

\author{
Gabrijela Pecimotika'; Krešimir Krizmanić'; Damir Rakarić², \\ Dražen Brajković ${ }^{3}$ \\ ${ }^{1}$ INA - Industry of Oil Plc., Lovinciceva 4, 10002 Zagreb, Croatia \\ ${ }^{2}$ INA - Industry of Oil Plc., Šubićeva 29, 10000 Zagreb, Croatia \\ ${ }^{3}$ Preradovićeva 29, 10000 Zagreb, Hrvatska
}

\begin{abstract}
By applying a palynological analysis of the Late Neogene sediments from one exploration well in the area of Eastern Slavonia, three vegetation zones $\left(\mathrm{Z}_{1}, \mathrm{Z}_{2}, \mathrm{Z}_{3}\right)$ as conditioned by climate sensitivity were set. On the basis of mutual percentage relations of the occurrence of individual form-species and grouping them according to the results of cluster analysis, these zones reflect the changes of warm-cold and variable humidity periods. The age of zones has been determined: zone $Z_{1}$ is Pontian, zone $Z_{2}$ is Pliocene and zone $Z_{3}$ is Pleistocene-Holocene. In the Pontian, 13 form-species of spores were determined that do not cross the Miocene/Pliocene boundary. In the Pliocene, 4 index form-species of spores were determined that were not found in the Quaternary in the study area. In the youngest sediments of the study area, i.e. Pleistocene and Holocene, 7 index form-species of spores were determined. Together with well logging (gamma ray and specific resistivity logs) of the formation, a model was constructed for the local routine provision of age in the study area. The results are generally consistent with other results obtained from Early Neogene sediments in adjacent areas in the central part of Paratethys, and may serve as a model for the correlation of contemporaneous sediments in other areas of Croatia, e.g. Sava and Drava Depressions, which in effect may contribute to the more efficient investigation of potential hydrocarbon reservoirs.
\end{abstract}

\title{
Keywords
}

Eastern Slavonia, Neogene, pollen, spores, climate, vegetation zones

\section{Introduction}

The area of Eastern Slavonia includes the southern part of the Pannonian Basin System (the eastern part of Drava and part of the Slavonia-Srijem Depressions) and it is one of the richest oil and gas fields in Croatia (Figure 1). The problem in the dating of Neogene sediments in further hydrocarbon exploration is always actual, because of the nature of their origin, as a consequence of environmental conditions of the sediment deposition and tectonic events at those times. The knowledge of the age of sediments which are reservoirs of hydrocarbons is the condition without which it is not possible to correlate contemporaneous layers, and thus define the potential of a petroleum system. During Neogene, the Paratethys area, because of tectonic movements, small grounding sedimentary basin systems were created with local environmental features, for example variability in the decrease of salinity degree, which resulted in endemism. Due to this fact, it is difficult or almost impossible to use index fossils characteristic of large, primarily marine depositional settings as a correlation tool of these isolated, more or less low salinity-brackish-freshwater environments. Due to the fact that spores and pollen are regionally distributed and they do not directly depend on the facies of depositional settings, palynology is the only tool in biostratigraphic correlation of sediments deposited in different continental and aquatic facies.

In terms of structural-tectonic and lithological features, the exploration area is quite complex. Many authors have dealt with this complex geological structure (e.g., Kranjec, 1972; Hernitz, 1983; Pamić, 1997; Pavelić, 2001, 2002, Saftić et al., 2003; Malvić \& Velić, 2011 ).

Igneous, metamorphic and sedimentary rocks of the Paleozoic, Mesozoic (locally possible and Palaeogene) are present in the explored area, and they represent the base of the Neogene sediments. Although the opening of the Pannonian Basin System (Rögl \& Steininger, 1984) started in Early Miocene as a result of the collision of two tectonic plates (the Eurasian and African plates), the evolution of most of its south-western and southern parts, including Eastern Slavonian part, started 
in the Lower Miocene (Ottnangian-Carpathian) triggered by strong extensional tectonics, volcanic activity and locally predetermined by the deposition of uneven lithological composition, varying, at first from freshwater to transitional and then to Badenian marine environments. Along with a variety of volcanic rock, the coarse freshwater sediments, breccia, conglomerate, sandstone, marl and limestone are deposited (Lučić et al., 2001; Pavelić et al, 2003). During the Middle Miocene in the shallow marine environment, mostly biogenic limestone and coarse-grained clastics were deposited, while in somewhat deeper environments, fine-grained sandstone, clay-marl and argillaceous limestone were deposited. In the Sarmatian, at the end of the Middle Miocene, the link between marine Paratethys and the great Mediterranean Sea (Tethys) breaks. The terrestrial influence caused the decrease of salinity and the deposition of a thin layered marl occurred. Upper Miocene sequence of sediments is characterized by a further gradual decrease of salinity and the deposition of a thick series of marl and sandstone. In the Pliocene, mostly sandy-clay sediments were deposited, and the succession ends by a deposition of Quaternary sediments represented by gravel, sand, clay and loess.

The aim of this study is to contribute to the more precise dating of the targeted sediments, in addition to the existing palynological results (dinosporine dinoflagellate cysts), by reconstructing the terrestrial vegetation, using spores and pollen, which depended on the climate typical of certain geological periods. Standard palynological analysis, statistical methods of pollen analysis and well logging measurements of natural radioactivity and specific resistivity of the formation, were used. The results will serve as a local model for routine dating of these sediments in the study area.

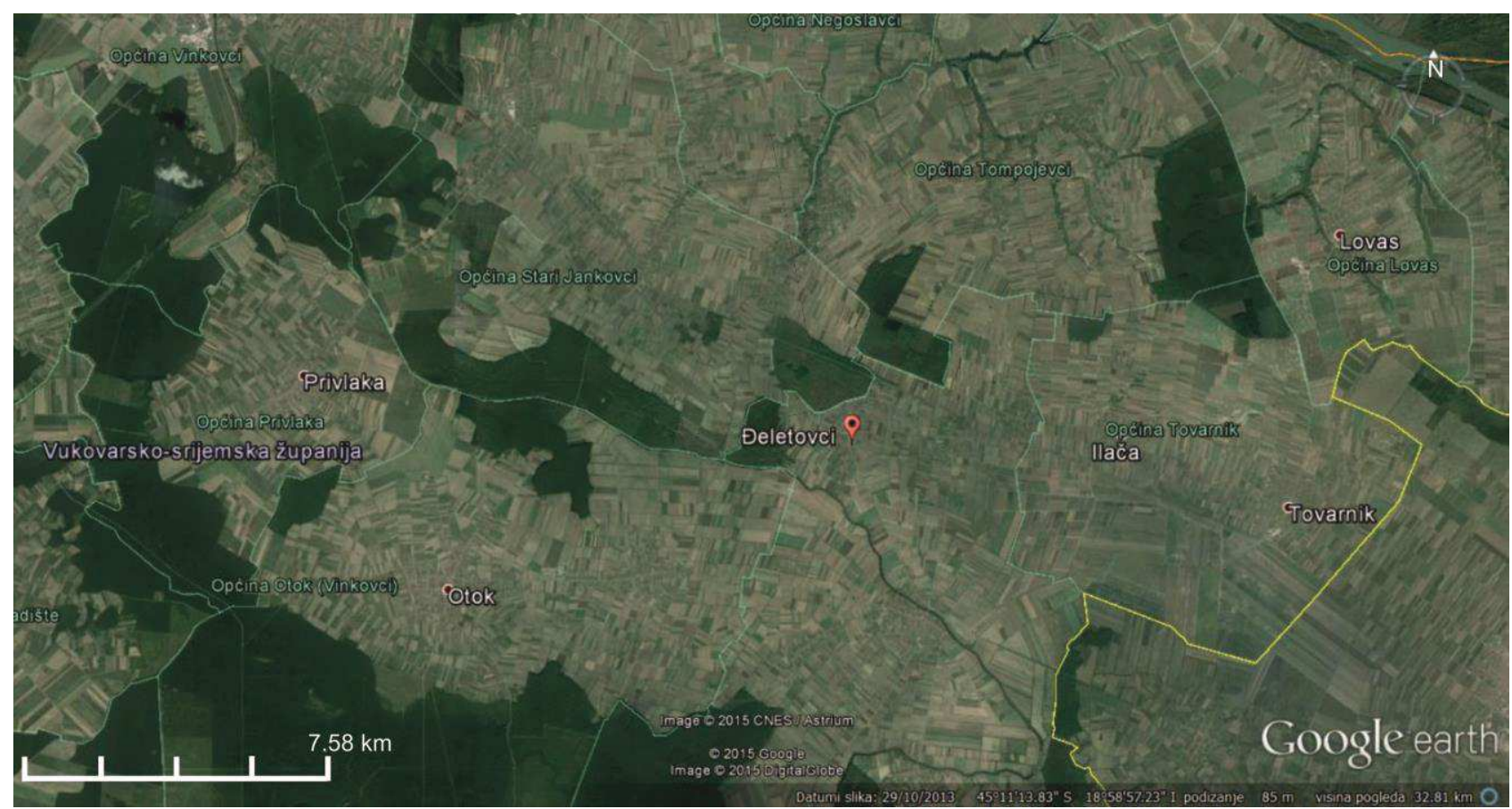

Figure 1. Geographic position of the study area (Modified from http://maps.google.hr/).

\section{Material and methods}

To create pollen diagrams, samples of debris from mud deep wells for the exploitation of hydrocarbons in Eastern Slavonia were used. The samples were taken every $30 \mathrm{~m}$ from the depths of $190 \mathrm{~m}$ to $1050 \mathrm{~m}$ for maceration. Maceration was performed according to the standard method (Kummel \& Raup, 1965) used in INA d.d. Washed samples were first treated with $18 \%$ hydrochloric acid $(\mathrm{HCl})$ to dissolve the carbonate, and after washing, the residue was treated with 40 $\%$ hydrofluoric acid to dissolve silica. The residue obtained by chemically dissolving the rock sample is further processed in $\left(\mathrm{ZnCl}_{2}\right)$ heavy liquid $(\varrho=2.1 \mathrm{~kg} / \mathrm{l})$. The heavy liquid is used to extract the organic material from the mineral. The supernatant from the organic residue is sieved through a $15 \mu \mathrm{m}$ sieve. The residue organic material was washed from the sieve, and centrifuged at $3600 \mathrm{rpm}$ for 10 minutes. The residue from the casting ring is applied to a glass slide, dried, and after the addition of glycerine gelatine, it is covered with a cover slip. A transmitted light microscope (Olympus BX51) $\mathrm{x}$ 600 and $\mathrm{x} 1000$ (oil immersion) was used for identification and x 400 was used for the counting of pollen and spores. Pollen and spore identification was accomplished using a computer program with a key to pollen and spore classes and a pollen database (Brajković et al., 2004). Other published keys and pollen atlases were also used as well as atlases of 
recent pollen (Reille, 1992, 1995), the key for recent pollen detection with pictures (Moore, 1991), and the Atlas of formspecies of fossil spores and pollen (Nagy, 1969; Planderová, 1990; Stuchlik et al., 2001). For the statistical analysis and preparation of pollen diagrams, computer software POLPAL was used (Walanus \& Nalepka, 1999).

\section{Results and discussion}

A total of 35 samples (every $30 \mathrm{~m}$ ) were analyzed, of which 30 (190-1050 m) contained palynomorphs (spores, pollen and dinocysts). Based on these, over 9000 pollen grains and spores (about 300 grains per sample) 96 taxa were determined, they were statistically processed and presented in the block diagram of the pollen, which consists of EK charts with a lithological column, a view of the development of each species in the study area during the time from the upper part of the Pontian (Stevanović, 1989) to the Holocene, cluster analysis and a chart of the relations of "warm and cold" species. The following results were obtained.

\section{I. Vegetation zones}

Three vegetation zones $\left(Z_{1}, Z_{2}\right.$ and $\left.Z_{3}\right)$ were determined on the basis of mutual percentage relations of the occurrence of individual species and grouping them according to the results of cluster analysis (Appendix 2). The biostratigraphical zone $Z_{1}$ is characterized by the dominance of pollen Taxodiaceae with a percentage up to $24 \%$, Alnus up to $11 \%$ and Ulmus up $9 \%$, indicating a warm and humid climate. At the top of the zone, at the turn of the Upper Pontian in the Pliocene, the percentage of Taxodiaceae are still high, while the percentage of Poaceae is markedly increasing (up $22 \%$ ), indicating a still moist but significantly colder climate. In the zone $Z_{2}$ the percentage of Taxodiaceae has declined, while the percentage of Alnus and Ulmus remains largely the same. The increase in the proportion of Cathaya (up to $4.5 \%$ ) and Asteraceae (up to $8 \%$ ) is remarkable. The turn of $Z_{2}$ into $Z_{3}$ is characterized by an increase in the percentage of Sciadopitys (up to $13 \%$ ) and Tsuga (up to $9.5 \%$ ). The zone $\mathrm{Z}_{3}$ is characterized by further cooling with the increasing percentage of Poaceae pollen (up to $17 \%$ ), Picea (up to $8 \%$ ), Tsuga (up to $8 \%$ ) and Abies (up to $6 \%$ ). This zone is divided into two sub-zones $\mathrm{Z}_{3 \mathrm{a}}$ and $\mathrm{Z}_{3 \mathrm{~b}}$. The zone $\mathrm{Z}_{3 \mathrm{a}}$ is characterized by a significant percentage of pollen genus Tilia (up to $6 \%$ ), Quercus (up to $5 \%$ ), and Fagus (up to $4.5 \%$ ), while in the zone $Z_{3 b}$ after the complete termination, the reappearance of Taxodiaceae pollen and Cupressaceae, Carya and Pterocarya is occurring, which are typical of riparian forests. This pollen diagram indicates a general cooling from Late Miocene to Quaternary, with distinct peaks on the border Pontian/Pliocene, Pliocene/Pleistocene and the end zone $\mathrm{Z}_{3 \mathrm{a}}$, and re-warming in zone $\mathrm{Z}_{3 \mathrm{~b}}$. Similar climatic events were registered in other parts of the central Paratethys. Vegetation in the Pontian in the Danube basin system indicates a more continental climate with less rainfall and higher humidity at the beginning of Pliocen (Kováč et al., 2006). In the area of the Forecarpathian Basin System in Northwestern Bulgaria (Ivanovet al., 2002) as well as in Serbia (Utescher et al., 2007) and Southeast Europe (Ivanov et al., 2011) and in the study area of Eastern Slavonia, at the time of the Pontian, vegetation of the riparian forest and the similar composition of plant communities indicates an identical climate picture. Further to the north, in the Pannonian Basin System in Southern Hungary, at the end of the Pleistocene the basal red clay was deposited (Kovács et al, 2011), and its mineral composition shows extreme cooling which is also registered in the pollen diagram from Eastern Slavonia.

\subsection{Age}

The age zone of $Z_{1}$, based on the dinocyst Galeacysta etrusca CORRADINI \& BIFFI (Plate 1) has been defined as Pontian. Zone $Z_{2}$ has been defined as Pliocene and zone $Z_{3}$ as Quaternary, or Pleistocene and Holocene respectively. In this study, they were determined by reconstructing the climate based on the mutual percentage ratio of individual species over time, and comparing diagram relations of "warm and cold" species (Appendix 2) with Haq's curve (Haq et al., 1987, 1988) changes of the sea level that considers global cooling and warming of the earth and a comparison with the method of oxygen isotopes ( $\delta \mathrm{O} 18$ ) that considers global climate changes (Emiliani \& Edwards, 1953). The block diagram of the pollen samples from the borehole shows three distinct cooling periods corresponding to the events on the border of Miocene / Pliocene (approx. $660 \mathrm{~m}$ ), Pliocene/Pleistocene (approx. $440 \mathrm{~m}$ ) and Quaternary (Pleistocene+Holocene) (260 m) (Appendix 2). 


\subsection{Index of fossil spores}

In the study area, the 44 form-taxa of spores were determined, 12 of which were form-genus and 32 form-species (Appendix 1). For each form-taxa the range of appearance has been determined within the investigated sediments (Appendix 3). Within each zone, the form-species of spores were determined, that appear only inside them, as possible index form-species for routine determination of age sediments in Eastern Slavonia. In the Pontian, 13 form-species of spores were determined, which do not cross the boundary Miocene/Pliocene (Plate 1). These are: Echinatisporis longechinus, Echinatisporis miocenicus, Laevigatosporites gracilis, Leiotriletes triangulus, Retitriletes pseudoclavatus, Retitriletes punctoides, Stereisporites cyclus, Stereisporites pseudopsilatus, Stereisporites stereoides, Stereisporites stictus, Verrucatosporites favus, Verrucatosporites megabalticus and Verrucatosporites megafavus. In the Pliocene, the 4 possible index form-species of spores were determined, that were not found in the Quaternary in the study area (Plate 2). These are: Distancoraesporis silesicus, Selagosporis selagoides, Verrucatosporites alienus and Verrucatosporites histiopteroides. The youngest sediments of the study area, the Pleistocene and Holocene, contain 7 possible index formspecies of spores (Plate 2): Camarozonosporites minoris (Lycopodiella sect. Campylostachys), Corrugatisporites microvallatus (Lygodium), Leiotriletes microlepioidites (Dennstaedtiaceae, Microlepia ?), Leiotriletes neddenioides (Lygodiaceae? Cyatheaceae?), Polypodiaceoisporites saxonicus (Pteris), Retitriletes rotundoides (Lycopodium) and Segmentizonosporites paucirugosus (Pteridaceae). The confirmation of the above form-species is to be expected in future analyses of this study area.

\subsection{Lithology and EK markers}

The comparison of the pollen diagrams with logging diagrams should enable the determination of the exact depth of the above geological boundaries, i.e. the position of the logging rappers $\alpha$, h and Q (Hernitz, 1983) (Figure 2). The youngest lithostratigraphic formation in Eastern Slavonia is the Vuka Formation (Šimon, 1966). It includes the interval above the logging marker alpha $(\alpha)$ to the surface. Based on lithological features, we can distinguish three parts of the Vuka Formation, which Batušić \& Urbiha (1979) called "operational units" A, B and C (from oldest to youngest) (Figure 2). In zone $\mathrm{C}$, which goes back to the surface, there is clay, loosely packed sandstones, gravel, loess and humus. In some places there are layers of poorly carbonized coal and peat (porosity sands is around $10 \%$, and the salinity of formation water does not exceed $0.5 \mathrm{~g} \mathrm{NaCl} / \mathrm{dm} 3$ ).

Ek marker "Q" divides zones B and C. Zone B is dominated by fine-grained sands with layers of clay of low plasticity (porosity sands is around $30 \%$, and the salinity of formation water $0.5-1 \mathrm{~g} \mathrm{NaCl} / \mathrm{dm} 3$ ). Ek marker "h" divides zones $\mathrm{A}$ and $\mathrm{B}$. In zone A, there is clay and fine-grained sands (25-30\% porosity and formation water salinity of 1-3 g NaCl/dm3). The transition from the Vera to Vuka Formations is characterized by a sudden increase in the value of specific resistance of formation (usually over $20 \mathrm{ohm} \mathrm{x} \mathrm{m}$ ) which is associated with the formation water salinity change which rapidly decreases (EK marker alpha). The central part of the Vuka Formation is separated from the lower part (B/A) by the logging marker "h". The values of specific resistance formations are more "jagged" in zone B than in Zone A (particularly in sandstones and sands) (Figure 2). 


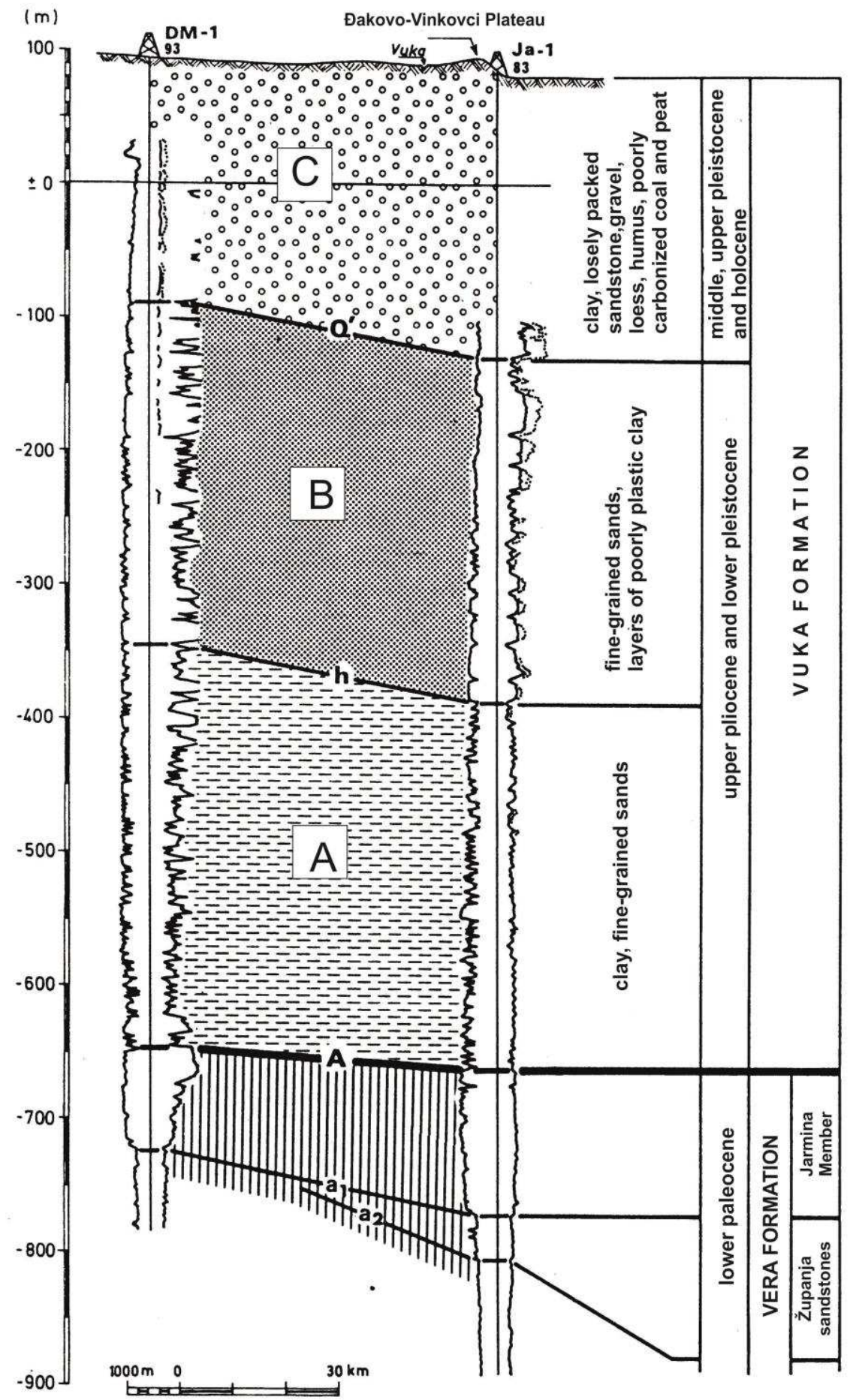

Figure 2. Classification of the Vuka Formation (modified from Hernitz, Z. 1983) 


\section{Conclusion}

From the debris of rocks obtained during the drilling of deep exploration wells in Eastern Slavonia, the pollen analyses were conducted and the pollen diagram was made showing the representation of certain plant species that existed in the area at the time of the uppermost Miocene to Quaternary. Three vegetation zones $\left(Z_{1}, Z_{2}\right.$ and $\left.Z_{3}\right)$ and two sub-zones $\left(Z_{3 a}\right.$ and $\mathrm{Z}_{3 \mathrm{~b}}$ ) were set.

Determined plant species were grouped according to environmental requirements in three groups - hot, cold and ubiquitous - that have a wide range of tolerance to climate change, primarily temperature. Their comparison led to determining the periods of extreme cooling in the study area throughout the observed time. The comparison with Haq's curve of global changes in sea level, and the comparison with the method of oxygen isotopes $(\delta \mathrm{O} 18)$ that shows global climate changes, led to determining the geological age of the established cooling periods.

The correlation of the results with curves EK measurements of the well, whose rock material was analyzed, led to the determination of accurate geological boundaries (Miocene/Pliocene and Pliocene/Quaternary) by using EK markers.

By precise provision of a range of occurrence of some form-species of spore, species that appear within a limited time period were set as possible index species for these geological periods in Eastern Slavonia. As such, they represent a valuable material for the routine determination of geological age in the study area.

Considering the specific development of the Miocene and Pliocene in the area of Central Paratethys, this model of research would be useful in other parts of the Pannonian Basin System.

\section{Acknowledgment}

We are grateful to Koraljka Bakrač and Georg Koch for carefully reviewing the manuscript and enabling us to significantly improve it. 


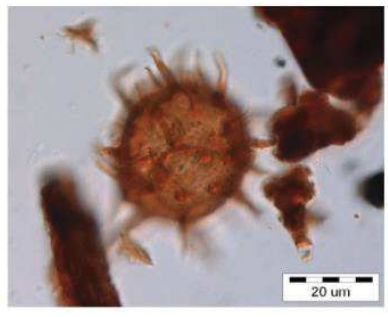

Echinatisporis longechinus

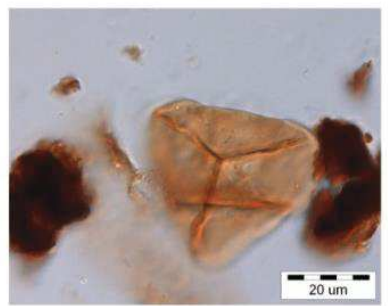

Leiotriletes triangulus

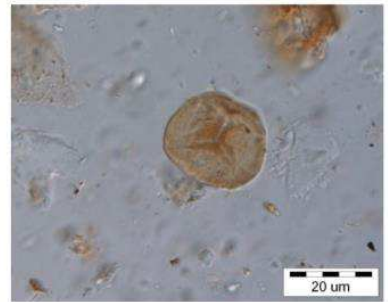

Stereisporites cyclus

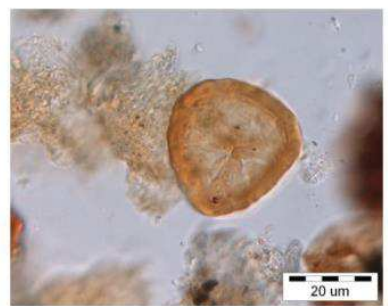

Stereisporites stictus

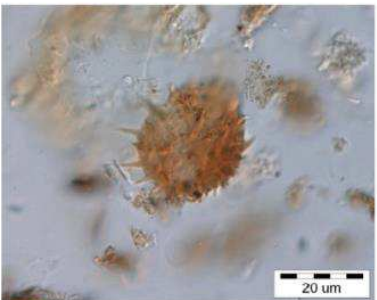

Echinatisporis miocenicus

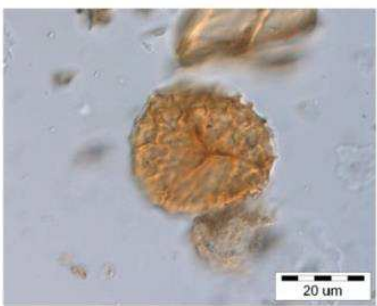

Retitriletes pseudoclavatus

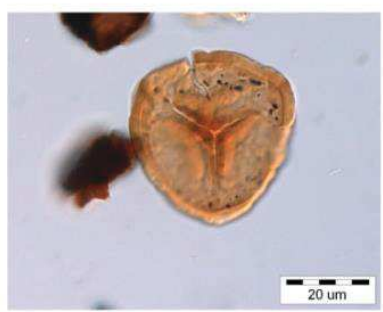

Stereisporites pseudopsilatus

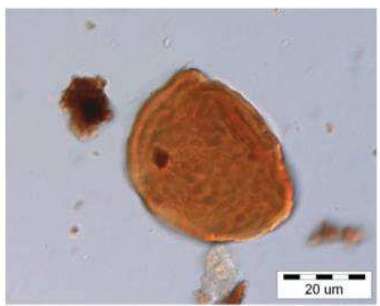

Verrucatosporites favus

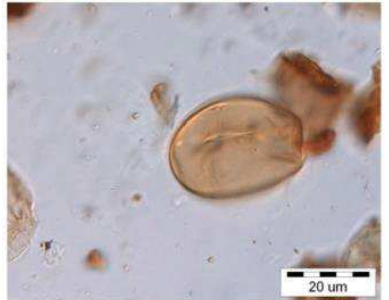

Laevigatosporites gracilis

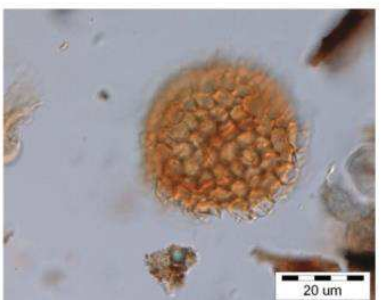

Retitriletes punctoides

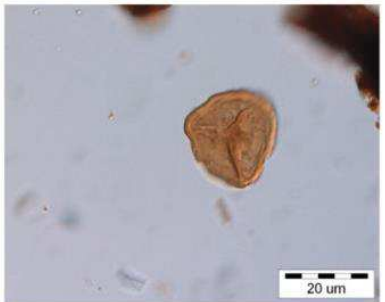

Stereisporites stereoides

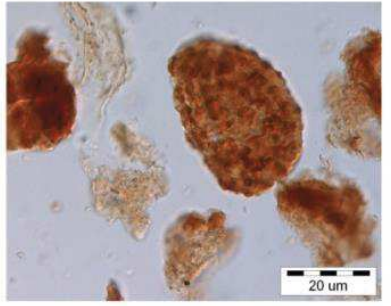

Verrucatosporites megabalticus

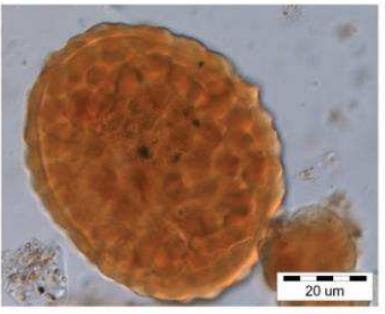

Verrucatosporites megafavus

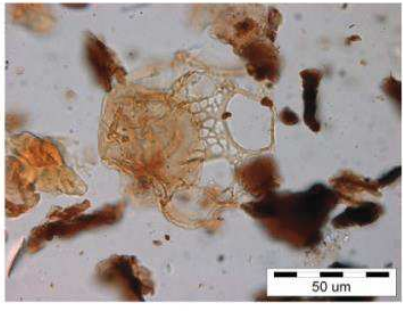

Galeacysta etrusca

Plate 1. 


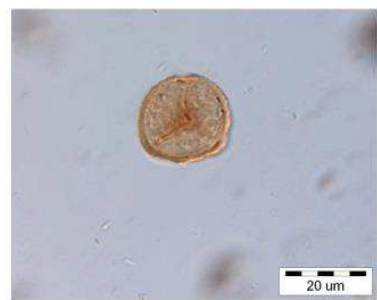

Distancoraesporis silesicus

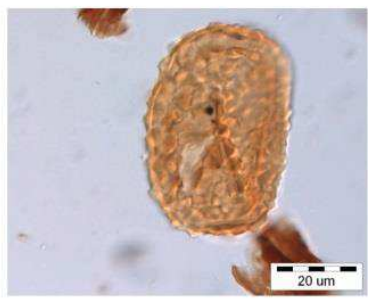

Verrucatosporites histiopteroides

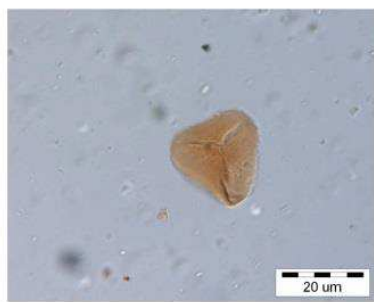

Leiotriletes microlepioidites

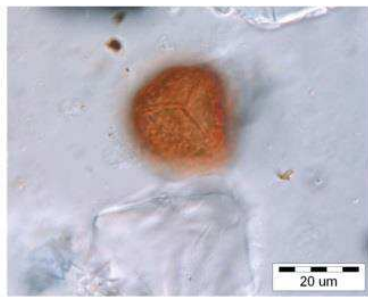

Selagosporis selagoides

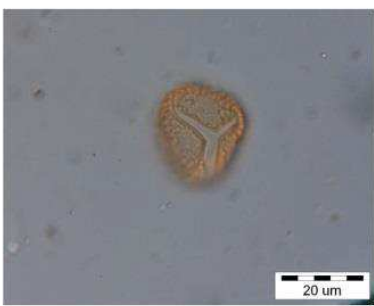

Camarozonosporites minoris

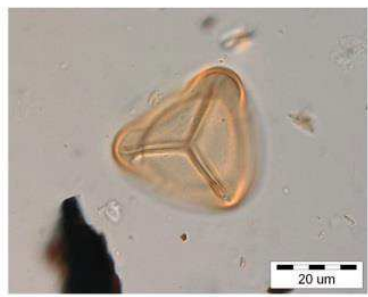

Leiotriletes neddenioides

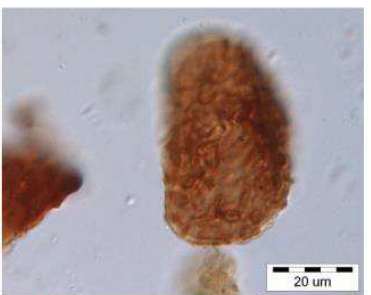

Verrucatosporites alienus

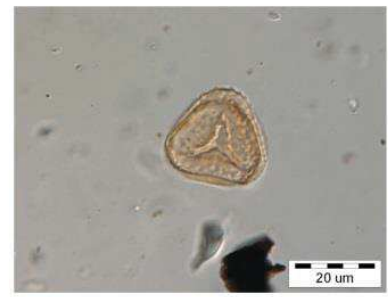

Corrugatisporites microvallatus

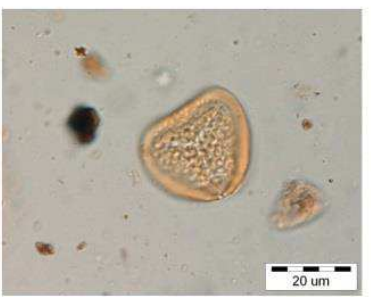

Polypodiaceoisporites saxonicus

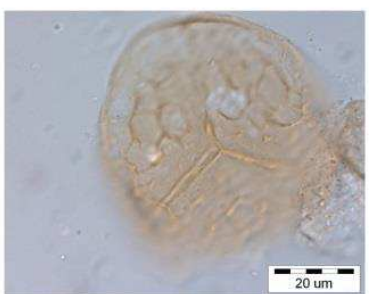

Retitriletes rotundoides

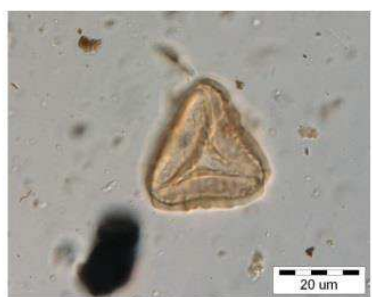

Segmentizonosporites paucirugosus

Plate 2. 


\section{Appendix 1}

\section{List of form-species of spores}

1. Baculatisporites sp.

2. Baculatisporites nanus (Wolff 1934) Krutzsch 1959

3. Baculatisporites ovalis Kedves 1973

4. Baculatisporites primarius (Wolff 1934) Pflug \& Thomson in Thomson \& Pflug 1953

5. Camarozonosporites minoris Krutzsch 1963

6. Contignisporites sp.

7. Corrugatisporites sp.

8. Corrugatisporites microvallatus (Krutzsch 1967) Nagy 1985

9. Distancoraesporis silesicus (Krutzsch 1963) Grabowska 2001

10. Echinatisporis sp.

11. Echinatisporis longechinus Krutzsch 1959

12. Echinatisporis miocenicus Krutzsch \& Sontag in Krutzsch 1963

13. Echinosporis fotensis Nagy 1985

14. Laevigatosporites $\mathrm{sp}$.

15. Laevigatosporites gracilis Wilson \& Webster 1946

16. Laevigatosporites haardti (Potonié \& Ventiz 1934) Thompson \& Pflug 1953

17. Leiotriletes $\mathrm{sp}$.

18. Leiotriletes microlepioidites Krutzsch 1962

19. Leiotriletes neddenioides Krutzsch 1962

20. Leiotriletes triangulus (Mürriger \& Pflug ex Krutzsch 1959) Krutzsch 1962

21. Neogenisporis sp.

22. Polypodiaceoisporites sp.

23. Polypodiaceoisporites saxonicus Krutzsch 1967

24. Retitriletes sp.

25. Retitriletes pseudoclavatus Krutzsch 1963

26. Retitriletes punctoides Krutzsch 1963

27. Retitriletes rotundoides Krutzsch 1963

28. Segmentizonosporites paucirugosus (Nagy 1985) Stuchlik 2001

29. Selagosporis selagoides Krutzsch 1963

30. Stereisporites $\mathrm{sp}$.

31. Stereisporites cyclus Krutzsch 1963

32. Stereisporites pseudopsilatus Krutzsch 1959

33. Stereisporites stereoides (Potonié \& Ventiz 1934) Thompson \& Pflug 1953

34. Stereisporites stictus (Wolff 1934) Krutzsch 1963

35. Toroisporis sp.

36. Toroisporis stuchlikii Planderová 1990

37. Triplanosporites sp.

38. Verrucatosporites sp.

39. Verrucatosporites alienus (Potonié 1931) Thompson \& Pflug 1953

40. Verrucatosporites balticus (Krutzsch 1962) Krutzsch 1967

41. Verrucatosporites favus (Potonié 1931) Thompson \& Pflug 1953

42. Verrucatosporites histiopteroides Krutzsch 1962

43. Verrucatosporites megabalticus Krutzsch 1967

44. Verrucatosporites megafavus Krutzsch 1967 


\section{Appendix2}

Pollen diagram of exploration well from Eastern Slavonia

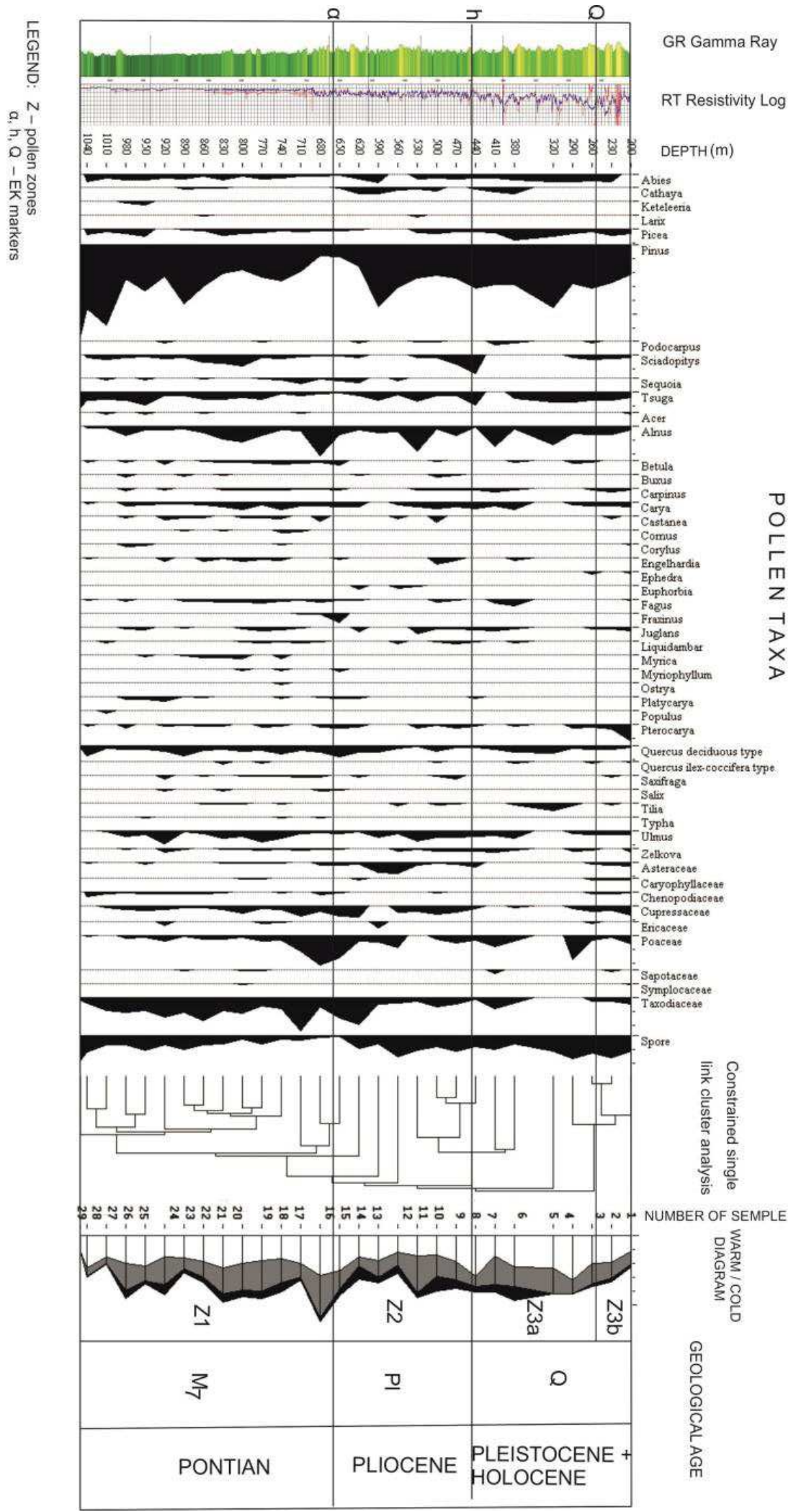

The Mining-Geology-Petroleum Engineering Bulletin, 2015, pp. 25-36 @ The Author(s), DOI: 10.17794/rgn.2015.2.3 


\section{Appendix3}

\section{Range of local index fossil spores}

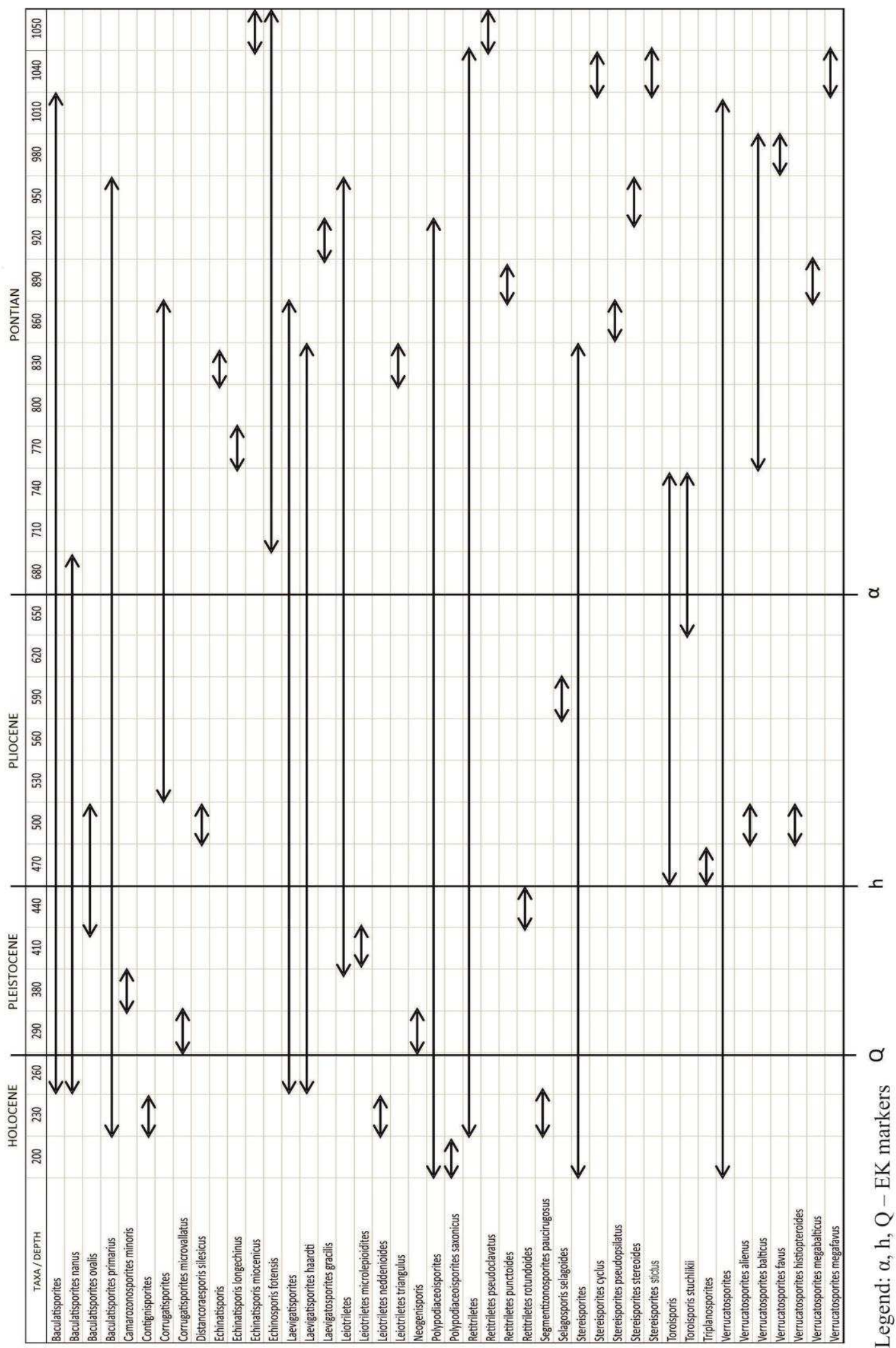

The Mining-Geology-Petroleum Engineering Bulletin, 2015, pp. 25-36 (C) The Author(s), DOI: 10.17794/rgn.2015.2.3 


\section{References}

\section{Published works:}

Batušić, V. \& Urbiha, H. (1979): O primjeni podataka iz naftnih bušotina za pridobivanje termomineralnih voda u Vuka-formaciji pliocena na području Donjeg Miholjca (About application of data in oil wells for recovering thermomineral water from Vuka Formation, Pliocene, in the area of Donji Miholac) . Zbornik radova III god. naučnog skupa I sekcije ZSN JAZU (Novi Sad, 1977), 2, 273-284. (in Croatian)

Brajković, D., Krizmanić, K., Donevski, B., Šoštarić, R., Kovačić, M., Mitić (2004): Croatian pollen database. XI International Palynological Congress, Granada, Spain. Polen 14, 599-600.

Emiliani C. \& Edwards G.(1953): Tertiary Ocean Bottom Temperatures. Nature, 171, 887-888.

Haq, B. U., Hardenbol, J., Vail, P. R. (1987): Chronology of fluctuating sea levels since the Triassic. Science, 235, $1156-1147$.

Haq, B. U., Hardenbol, J., Vail, P. R. (1988): Mesozoic and Cenozoic chronostratigraphy and cycles of sea-level changes. U: Wilgus, C. K. (ur.): Sea-Level Changes-an Integrated Approach. SEPM Spec. Publ., vol. 42, pp. 71-108.

Hernitz, Z. (1983): Dubinski strukturno-tektonski odnosi u području istočne Slavonije (Deep structural and tectonic relations in the Eastern Slavonia). Doctoral thesis, Nafta, special publication, Zagreb, 221 p. (in Croatian)

Ivanov, D., Ashraf, A.R., Mosbrugger, V., Palamarev, E. (2002): Palynological evidence for Miocene climate change in the Forecarpathian Basin (Central Paratethys, NW Bulgaria). Palaeogeography, Palaeoclimatology, Palaeoecology, 178, 19-37.

Ivanov, D., Utescher, T., Mosbrugger, V., Syabryaj, S., Djordjević-Milutinović, D., Molchanoff, S (2011): Miocene vegetation and climate dynamics in Eastern and Central Paratethys (Southeastern Europe). Palaeogeography, Palaeoclimatology, Palaeoecology, 304, 262-275.

Kranjec, V (1972): Subsurface structures in the Sava and Drava river depressions and their classification. bull. sci. Cons. Acad. Yugoslav., (A), 17/11-12, 362-363, Zagreb.

Kováč, M., Baráth, I., Fordinál, K., Grigorovich, A. S., Halásová, E., Hudáčková, N., Joniak, P., Sabol, M., Slamková, M., Sliva, L., Vojtko, R. (2006): Late Miocen to Early Pliocen sedimentary environments and climatic changes in the Alpine-CarpathianPannonian junction area: A case study from the Danube Basin northern margin (Slovakia). Palaeogeography, Palaeoclimatology, Palaeoecology, 238, 32-52.

Kovács, J., Fábian, S. Á., Varga Gabor, Újvári, G., Varga György, Dezső, J. (2011): Plio-Pleistocen red clay deposits in the Pannonian basin: A review. Quaternary International, 240, 35-43.

Kummel, B. \& Raup, D. (editors) (1965): Handbook of Paleontological Techniques. Part III, Elsevier, Amsterdam, 601-613.

Lučić, D., Saftić, B., Krizmanić, K., Prelogović, E., Britvić, V., Mesić, I., Tadej, J. (2001): The Neogene evolution and hydrocarbon potential of the Pannonian Basin in Croatia. Marine and Petroleum Geology, 18, 133-147.

Malvić, T. \& Velić, J. (2011): Neogene Tectonicsin Croatian Part of the Pannonian Basinand Reflectancein Hydrocarbon Accumulations. New Frontiersin Tectonic Research: At the Midstof Plate Convergence, Schattner, In Tech, 215-238, Rijeka.

Moore P. D., webb, J.A., Collinson, M. E. (1991): Pollenanalysis. Blackwell Scientific Publications. Oxford, London, 216 p.

Nagy, E. (1969): Palynological elaborations of the Miocene layers of Mecsek Mountains. Annales Instituti Geologici Publici Hungarici (Annales of Hungarian Geological Institute), 52, 2, 237-650.

Pamić, J. (1997). Vulkanske stijene Savsko-dravskog međuriječja i Baranje (Hrvatska) (Volcanic rocks of the Sava-Drava inter-river area and Baranja (Croatia)). Nafta, special publication, , $192 \mathrm{p..}$

Pavelić, D. (2001). Tectonostratigraphic model for the North Croatian and North Bosnian sector of the Miocene Pannonian Basin System. Basin Research, 13/3, 359-376. ISSN 0950-091X.

Pavelić, D. (2002). The south-western boundary of Central Paratethys. Geologia Croatica, 55, 1, 83-92.

Pavelić, D., Kovačić, M., Miknić, M., Avanić, R., Vrsaljko, D., Bakrač, K., Tišljar, J., Galović, I. \& Bortek, Ž.(2003): The Evolution of the Miocene Environments in the Slavonian Mts. Area (Northern Croatia). U: Vlahović, I. \& Tišljar, J. (ur.): Evolution of Depositional Environments from the Palaeozoic to the Quaternary in the Karst Dinarides and the PannonianBasin. 22nd IAS Meeting of Sedimentology, Opatija, September 17-19, 2003, Field Trip Guidebook, 173-181, Zagreb.

Planderová, E. (1990): Miocene microflora of Slovak Central Paratethys and its biostratigraphical significance. Dionýz Štúr Institute of Geology, Bratislava, $144 \mathrm{p}$.

Reille, M. (1992): Pollen et spores d'Europe et d'Afrique du Nord. Marseille, 520 p.

Reille, M. (1995): Pollen et spores d'Europe et d'Afrique du Nord. Supplement 1, Marseille, 327 p.

Rögl, F. \& Steininger, F. (1984): NeogeneParatethys, Mediterraneanand Indo-pacific seaways; u Fossilsand climate, Brenchey, P.J. (ur.), Geological Journal, special issue11, 171-200.

Saftić, B., Velić, J., Sztano, O., Juhas, G. \& Ivković, Ž. (2003): Tertiarysubsurfacefacies, sourcerocksand hydrocarbon reservoirs in the SW part of the Pannonian Basin (northern Croatia and south-westernHungary). GeologiaCroatica, 56, 1, 101-122.

Stevanović, P.M., Nevesskaya, L.A., Marinescu, F., Sokac, A., Jámbor, Á. (Ur.) (1989): Chronostratigraphie und Neostratotypen, Neogen der Westlichen ("Zentrale”) Paratethys VIII, P1 1, Pontien. Jazu and Sanu, Zagreb-Beograd, str. 1-952.

Stuchlik, L., Ziembińska-Tworzydło, M., Kohlman-Adamska, A., Grabowska, I., Ważyńska, H., Słodkowska, B., Sadowska, A. (2001): Atlas of pollen and spores of the Polish Neogene. Spores vol. 1. W. Szafer Institute of Botany, Polish Academy of Sciences, Cracow, $158 \mathrm{p}$. 
Utescher, T., Djordjevic-Milutinovic, D., Bruch, A., Mosbrugger, V. (2007): Palaeoclimate and vegetation change in Serbia during the last 30 Ma. Palaeogeography, Palaeoclimatology, Palaeoecology, 253, 141-152.

Walanus, A. \& Nalepka, D. (1999): POLPAL- programs for storage of pollen tables, diagrams ploting and numerical data analysis. W. Szafer Institute of Botany, Polish Academy of Sciences, Cracow, 25 p .

\section{Unpublished works:}

Šimon, J. (1966): Litostratigrafske jedinice tercijarnog kompleksa ist. Slavonije i korelacija s istim jedinicama Savske i istočnog dijela Dravske potoline. Fond struč. dok., INA d.d., Zagreb, 63 str. 